\title{
Training Media Learning for Teachers of MI Citra Taman Siswa
}

\author{
Author \\ Nur Hidayat \\ Correspondence \\ STKIP Bina Insan Mandiri, Jl. Raya Menganti Kramat 133 Wiyung and J1. Raya Benowo 1-3, Surabaya, Indonesia \\ E-mail: nurhidayat@stkipbim.ac.id
}

\begin{abstract}
This community program aims to increase understanding and awareness to educators about the importance of media in the learning process. The subjects of this activity are the teachers of MI Citra Taman Siswa Menganti. In the implementation of this activity, the method used is lecture, question and answer, discussion and practice. The result of the activity shows that with the learning media training activities can improve the understanding and ability of MI Citra Taman Siswa teachers in using media in the learning process. The result of the community program suggests the school to provide supporting training activity with other relevant institution. Finally, the quality of training has to be carefully taken into account to improve teachers' professionalism.
\end{abstract}

Keywords: training, media learning, community program

\section{Introduction}

The teacher (educator) is the core facilitator in the learning process where one of the functions and duties of a teacher is to provide an effective and interesting learning activity for the learners. Samana (1994, p.16) explains that the main factor in improving the quality of learning in the classroom is the teacher. Teachers become one of the main points that play an important role in pengelolahan process learning activities. In order for the implementation of learning activities more effective and interesting tool or media required in accordance with the needs of the learning process.

Media becomes one of the main components in the learning process. Media becomes important to realize effectiveness in the delivery of material and able to grow interactive nature in learning (Azhar, 1997, p.15). In addition, the use of media in the learning process can affect the condition, motivation and learning environment (Hamalik, 1990). Seen from the side of the media benefits are so great and positive in learning it is indirectly it becomes recommended even required for an educator to mapu have ability in making learning media. But until now there are still many educators who do not have the ability or not have the motivation to make learning media so that productivity of educators in the making and use of
Received: 15 December 2017. Accepted: 15 January 2018

media is still considered minimal. This is influenced by the many tasks of educators in terms of fulfillment of school administration, certification and lack of learning media training activities undertaken by either the government or the school.

Based on the above information, the writer wants to do instructional media training to improve teacher's understanding in compiling, selecting \& using instructional media in the classroom especially for MI Citra Taman Siswa Menganti teachers, where the school is only about 5 years running so that the existing media and its use in learning is still lacking.

\section{Method \\ Implementation Method}

The methods used in this learning media training activities are:

\section{Lecture}

Lectures are used in explaining about learning media materials that include: understanding of learning media, the function of instructional media, media by type, media based on making and media selection steps. Besides, it is also conveyed about the importance of learning media in the learning process for educators and learners and motivation from the speakers to the participants to create 
learning media. In the use of this lecture method, speakers also use the LCD as a support tool to provide an overview of the learning media. The presenters also display videos about the use of learning media and words of wisdom and provide Ice breaker to make the atmosphere more interesting and fun.

2. Question and answer

Questions and answers are carried out simultaneously with the process of delivering the material by the resource person. The presenters give the participants maximum time to ask questions without having to be limited to the maximum number of questions asked. The speakers use the metoode to make the activity more interactive without having to wait for the questioning session to make it easier for participants to submit questions without any forgetful fears.

\section{Group Discussion}

The group discussion was held at the end of the session after the presentation of the material was carried out. The presenters gave the time as much as possible in the discussion in each material. The presenters also divided the participants into 5 groups, each group consisting of 2 people. Each group was given some questions about instructional media that they had to finish with a logical explanation. In addition they are also given the opportunity to ask each other questions or give opinions to the answers in each group.

\section{Practice}

Practice in this activity is the practice in using the media in the learning process that has been provided by the speaker. In this case due to time constraints, the speakers divide the participants into 2 groups. Where the two groups are asked to explain the use of ulema media and practice it for the subjects they hold. In this case the speaker gives 15 minutes to each group in explaining and practicing briefly about the use of the media.

\section{Preparation for Community Service Activities}

Before the activity is carried out, the following preparations are made:

1. Preparing tools and materials for training of learning media SD/MI.

2. Determine the timing of implementation and duration of service activities.
3. Determine and prepare the material to be delivered in community service activities.

\section{Subject}

The subject of this activity is the teachers of MI Citra Taman Siswa located in Menganti Gresik Subdistrict. Implementation of these activities took place at the school MI Citra Taman Siswa Menganti Gresik. The implementation of the devotion activity takes place on Saturday, February 18, 2017 from 08.00 s.d 12.00 WIB.

\section{Relevance for Society}

This devotional activity has relevance to the needs of teachers and schools in order to improve the quality of teachers in understanding the aspects of instructional media as well as the importance of media in the ongoing learning process.

\section{Results And Discussion \\ Training Results}

The results of instructional media training activities are as follows:

1. The training was attended by 10 of the 15 classroom teachers in MI Citra Taman Siswa.

2. The material presented is a learning medium that includes: understanding of learning media, the function of learning media, media by type, media based on the creation and steps of media selection.

3. Training runs smoothly and effectively. In addition, the provision of motivation in the form of video and Ice breaker can increase the enthusiasm of participants in the training.

4. Increased knowledge and insight of teachers Citra Taman Siswa about learning media. It is known from the observation discussion, question and answer and practice that took place in the activity.

\section{Supporting and inhibiting factors}

Several factors that support the implementation of this activity is the amount of interest and enthusiasm of the participants during the activities, so that the activities take place smoothly and effectively. While the inhibiting factor is limited training time. 


\section{Conclusion and Suggestion}

\section{Conclusion}

From the activities of community service this can be concluded that:

1. The knowledge and understanding of MI Citra Taman Siswa teachers on learning media SD / MI increases.

2. The skills and insights of MI Citra Taman Siswa teachers on the application of learning media SD/MI is increasing.

\section{Suggestion}

Given the magnitude of the benefits of community service, then it is necessary to:

1. Provide similar training to other schools as well as a wider range of different target audiences by working with relevant agencies.

2. Time allocation of activities needs to be increased to improve the quality of the training.

\section{References}

Arsyad, A. (1997). Media Pembelajaran. Jakarta: PT Raja Grafindo Persada.

Hamalik, O. (1990). Metode Belajar dan Kesulitan- Kesulitan Belajar. Bandung: Tarsito.

Samana, A. (1994). Profesionalisme Keguruan. Yogyakarta: Kanisius. 